\title{
OPEN Evaluation of the performance and gas emissions of a tractor diesel engine using blended fuel diesel and biodiesel to determine the best loading stages
}

\author{
Haitham Emaish ${ }^{1 \bowtie}$, Khamael M. Abualnaja ${ }^{2}$, Essam E. Kandil ${ }^{3}$ \& Nader R. Abdelsalam ${ }^{4} \bowtie$
}

Fossil fuels are the main energy sources responsible for harmful emissions and global warming. Using biodiesel made from waste deep-frying oil as an alternative fuel source in diesel engines has drawn great attention. This biodiesel is produced using the transesterification process and blends with mineral diesel at Faculty of Agriculture Saba Basha, Alexandria University, Egypt. The turbocharged diesel engine of a Kubota M-90 tractor was tested. The objectives of this work are to test tractor as a source of power in the farm using waste deep-frying oil biodiesel to utilize waste frying oils (WFO) in clean energy production on the farm and determine the best engine loading stages to maximize engine efficiencies for different fuel blends and reduce the environmental impact of gas emissions from tractor diesel engines in the farms. The experiment design was factorial, with two factors, where the first was the engine load $(0 \%, 25 \%, 50 \%, 75 \%$, and $100 \%)$ and the second was fuel blend $(0 \%$, $5 \%, 20 \%$, and $100 \%$ biodiesel), and the effects of loading stages and biodiesel percentage on engine performance indicators of engine speed, power take off torque, power take off power, brake power, brake mean effective pressure, brake thermal efficiency, brake specific fuel consumption, and gas emissions were studied. The experimental results indicated that engine load percentage and fuel blend percentage significantly affected all studied characters, and the best engine loading stages were between 25 and $75 \%$ to maximize engine efficiency and minimize the specific fuel consumption and gas emissions. Increasing the biodiesel percentage at all loading stages resulted decreasing in Engine brake power (BP), brake thermal efficiency, Power take-off (PTO) torque, and brake mean effective pressure and increases in brake specific fuel consumption. Increasing the engine load resulted in decreases in $\mathrm{O}_{2}$ emissions and increases in $\mathrm{CO}_{2}, \mathrm{CO}, \mathrm{NO}$, and $\mathrm{SO}_{2}$ emissions. Increasing the biodiesel percentage in the blended fuel samples resulted in increases in $\mathrm{O}_{2}$ and $\mathrm{NO}$ emissions and decreases in $\mathrm{CO}_{2}, \mathrm{CO}$, and $\mathrm{SO}_{2}$ emissions. The use of biodiesel with diesel fuel reduces the environmental impact of gas emissions and decreases engine efficiency.

Fossil fuels are the main energy sources responsible for harmful emissions and global warming. Increases in energy consumption are generating a greater reliance on fossil fuels and are vastly increasing carbon dioxide emissions, leading to environmental pollution, especially in the transportation sector, where the highest consumption of liquid fuel is found ${ }^{1}$. Biodiesel is a clean fuel source for diesel engines, produced by a chemical reaction between a vegetable oil and methanol or ethanol alcohol in the presence of a catalyst ${ }^{2}$. Waste frying oil (WFO) are related for deep frying with high heat temperatures $\left(150-190^{\circ} \mathrm{C}\right)$, it is a spent vegetable oil that used for deep frying and no more viable for further consumption ${ }^{3-5}$. But cooking oils are large range of all oil types that used for common cooking ${ }^{6}$. Biodiesel is made from fresh vegetable oils, such as, palm oil, sunflower oil, soybean

\footnotetext{
${ }^{1}$ Department of Soils and Agricultural Chemistry, Biosystem Engineering, Faculty of Agriculture, (Saba Basha), Alexandria University, P.O. Box 21531, Alexandria, Egypt. ${ }^{2}$ Department of Chemistry, College of Science, Taif University, P.O. Box 11099, Taif 21944, Saudi Arabia. ${ }^{3}$ Plant Production Department, Faculty of Agriculture, (Saba Basha), Alexandria University, P.O. Box 21531, Alexandria, Egypt. ${ }^{4}$ Agricultural Botany Department, Faculty of Agriculture, (Saba Basha), Alexandria University, P.O. Box 21531, Alexandria, Egypt. ${ }^{\bowtie}$ email: drhaitham1976@ alexu.edu.eg; nader.wheat@alexu.edu.eg
} 
oil, and so on, which can result in increased food prices ${ }^{7,8}$. The cost of feedstock is about $80 \%$ of production costs of biodiesel, so vegetable oils are too high for biodiesel production ${ }^{9,10}$. To solve this problem, waste frying oil is the best choice for biodiesel production because it is low-cost feedstock and non-edible oils ${ }^{11}$. In addition, unsafe disposal of waste frying oil results in environmental pollution. Therefore, to solve this problem, WFO was used as feedstock to produce biodiesel ${ }^{12,13}$.

The main characteristics of biodiesel are quite like those of mineral diesel. Biodiesel is compatible with mineral diesel and can be mixed in with different ratios. The replacement of mineral diesel with vegetable oils in diesel engines has detected some problems, particularly due to the lower volatility of vegetable oils and their higher viscosity, density, and molecular weight. Hence, it has been reported that the "transesterification process is the best method and the most common technology to produce biodiesel" 14 . The quality and the yield of the produced biodiesel depend on the type of raw material, as well as the process parameters (oil and methanol molar ratio, the catalyst type and quantity, reaction time and temperature and finally blending speed ${ }^{15}$.

Biodiesel is an alternative energy source for internal combustion engines. Diesel engines can run on vegetable oil as fuel and produce equivalent power to that produced by mineral diesel. The biodiesel mass flow energy delivery increases with the higher density and viscosity of the vegetable oil ${ }^{16}$. Using biodiesel made from waste frying oil is an alternative fuel source in diesel engines which drawn great attention. A biodiesel sample was converted from waste cooking oils and tested in a diesel-powered bus on a dynamometer. The performance of biodiesel were similar to those of mineral diesel, with the exception of a significant reduction of emissions during acceleration with biodiesel ${ }^{17}$. The performance of diesel engines using blended fuel consisting of $20 \%$ by volume of waste cooking-oil biodiesel and $80 \%$ of mineral diesel indicated that engine thermal efficiency decreased, and specific fuel consumption increased with increased biodiesel blends relative to diesel fuel ${ }^{2,18-20}$.

The performance of tractors using different fuel blends of mineral diesel and biodiesel was conducted in stationary and non-stationary conditions indicate the power of engine and drawbar power which decreased with the use of biodiesel and different fuel blends of biodiesel, while resulted in increase the specific fuel consumption ${ }^{21}$.

The effects of using different blends of palm biodiesel on the performance of a diesel engine showed a reduction in carbon monoxide emissions and unburned hydrocarbons (HC) emissions of about 46 and $73 \%$, respectively. Blended palm biodiesel $\left(\mathrm{B}_{20}\right)$ causes a reduction in exhaust emissions relative to mineral diesel ${ }^{22-24}$. The performance and emissions of diesel engines have been studied with the use of mineral diesel and biodiesel produced from soybean oil. The specific gravity and viscosity of biodiesel were higher than those of diesel fuel at $40{ }^{\circ} \mathrm{C}$. The heat of biodiesel combustion was $12 \%$ lower than that of mineral diesel. It was observed that smoke opacity and engine power were decreased by $71 \%$ and $4.8 \%$, respectively, when the engine was operated with biodiesel compared to mineral diesel. However, the maximum engine torque was decreased by about 6 and $3.2 \%$ at 1700 and $1300 \mathrm{rpm}$, respectively. A gas emissions test showed that increasing the biodiesel percentage resulted in decreases in $\mathrm{HC}$, carbon monoxide (CO), and oxides of nitrogen (NOx) by about 54 , 46, and $14.7 \%$, respectively, which resulted in increasing $\mathrm{CO}_{2}$ by about $0.5 \%$. This study was conducted to study the effects of blending waste frying oil (WFO) biodiesel with diesel fuel on the performance of a diesel engine and determine the best engine loading stages to maximize engine efficiencies for different fuel blends and reduce the environmental impact of gas emissions for diesel engines.

\section{Materials and methods}

Laboratory preparation of biodiesel. A waste frying oil (WFO) biodiesel sample was prepared and blended with mineral diesel in a laboratory at the Soil and Agricultural Chemistry Department, Faculty of Agriculture Saba Basha, Alexandria University, Egypt. The WFO was converted to biodiesel using transesterification. The amounts of methanol alcohol and catalyst $(\mathrm{NaOH})$ were determined using the titration process to improve the reaction rate and yield ${ }^{26}$.The optimum biodiesel transesterification process parameters are (A) Removing impurities from the WFO using filter paper; (B) Heating oil to $100^{\circ} \mathrm{C}$ to evaporate the water; (C) Cooling the oil to $60{ }^{\circ} \mathrm{C}$ to begin the reaction; (D) Molar ratio of $6: 1$ (6 mol of alcohol:1 mol of waste frying oil); (E) The catalyst also is commonly considered $1 \%$ of the oil weight unless is not determined from titration; (F) Mixing methanol and sodium hydroxide with the oil for $1 \mathrm{~h}$ and leaving them in a separator funnel for $1 \mathrm{~h}$ to separate the glycerol from the methyl esters; $(\mathrm{G})$ Heating distilled water to $60^{\circ} \mathrm{C}$ and slowly shaking it by hand with methyl esters before leaving it in a separator funnel for $15 \mathrm{~min}$ to separate suspended impurities and washing water from the methyl esters; $(\mathrm{H})$ Washing the methyl esters with distilled water until the water was pure at $\mathrm{pH}$ values between 6 and 7 and (I) Heating the biodiesel to $100^{\circ} \mathrm{C}$ to free it of water According to Ma and Hanna (1999) and Verma and Sharma (2016). Biodiesel properties are pour point $-7^{\circ} \mathrm{C}$ according to the method ASTMD-97; Ash content $\mathrm{wt} \%$ (Nil) according to ASTMD-482; Calorific value (Mj/kg) was 42.3 and Flash point $142{ }^{\circ} \mathrm{C}$ (ASTMD-93) ${ }^{27}$.

Performance evaluation of Kubota M-90 tractor. Fuel blends were tested using a direct-injection turbocharger diesel engine for a Kubota M-90 tractor (Kabuto-cho, Chuo-ku, Tokyoas, Japan) a source of farm power for various agricultural operations in the field.

The performance of the direct-injection turbocharger diesel engine of the Kubota M-90 tractor $(66.2 \mathrm{~kW})$ was determined using a hydraulic brake stationary dynamometer $(300 \mathrm{~kW})$ at the Testing and Research Station for Tractors and Agricultural Machinery, of the Agricultural Research Center, Alexandria, Egypt as shown in Fig. 1a,b. The engine specifications are [Tractor model: M-90 4 WD, Engine type: Direct-Injection turbocharger, Engine model: V4702-TL water cooled, Number of cylinders: 4, Total displacement, $\mathrm{cm}^{3}: 4665$, Bore and stroke, $\mathrm{mm}$ : $109 \times 125$, Net power kW (hp): $66.2(90)$, Power take-off $(\mathrm{PTO})$ power kW (hp): $52.6(71.5) / 2400$, and Max engine torque $\mathrm{Nm} / \mathrm{rpm}$ : 335/1200)]. The engine was left to run for $1 \mathrm{~h}$ to warm up all the parts so that they reached the best working temperature before the test was begun. The tractor power take-off (PTO) shaft related to the brake dynamometer, and then the engine was run at full throttle for all tests and left running for 


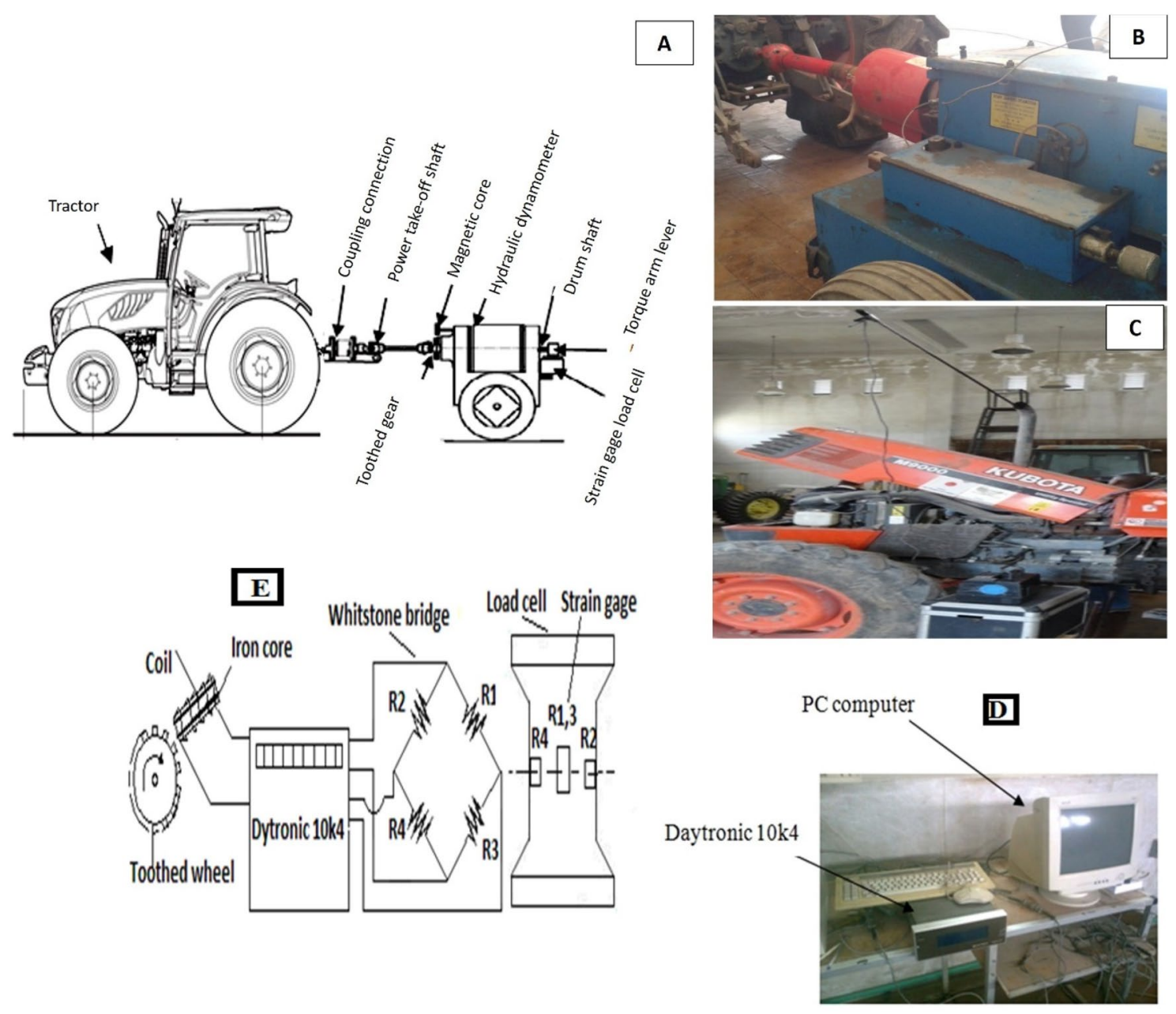

Figure 1. Tractor test equipment (A,B), connecting gas analyzer with the tractor (C), (D-E) A data acquisition system to save the measurements on the computer.

$10 \mathrm{~min}$ to consume fuel residue after the fuel type was changed before each test. Five loading stages of 0,25 , 50, 75 and $100 \%$ were selected for every test. The engine started up at no loading stage with maximum speed; dynamometer sensors and Daytronic (model 10k4, https://www.daytronic.com/resources/software-manuals/) was used to record measured data by the pick-up frequency and torque sensor according to ${ }^{28}$, which engaged to the hydraulic dynamometer. The torque sensor comprises of a full whinstone bridge of strain gage for record the torque exerted on PTO shaft during loading test. The pick-up frequency sensor was used to recording the rpm of the PTO shaft, which comprises of a toothed wheel and coil around an iron core, the magnetic field of the magnetized cause is detected when the toothed wheel rotates and displayed as rpm. A data acquisition system was used to save the measurements on the computer, as shown in Fig. 1d,e, the load on the PTO shaft was increased by using a hydraulic dynamometer until a max load of $100 \%$ was reached, which led to a minimum speed. The dynamometer was equipped with torque and speed sensors to measure the torque and speed of the PTO shaft at each loading stage. The performance indicators of the turbocharged diesel engine were calculated using the measured torque, speed of PTO shaft, fuel consumption, and time for each test. The quality of gas emissions was measured with a portable gas analyzer (NOVA 7460), which consists of electrochemical sensors and infrared flue gas analyzers to measure the temperature and the gas elements content of $\left(\mathrm{CO}_{2}, \mathrm{CO}, \mathrm{NO}, \mathrm{NO}_{\mathrm{x}}, \mathrm{O}_{2}\right.$, and $\left.\mathrm{SO}_{2}\right)$. The gas analyzer was calibrated in the laboratory by using analyzed calibration gases and all values were Zero on air before connected to the tractor exhaust pipe during the test, as shown in Fig. 1c.

Gas analyzer specification. The Portable Analyzers (7460 Series) are presented in 6 versions for the simultaneous measurement of the gases normally found in the exhaust from internal combustion engines. $\mathrm{HC}, \mathrm{CO}_{2}$, and $\mathrm{CO}$ are identified by a dual wavelength infrared sensor. The $\mathrm{NOx}, \mathrm{SO}_{2}$ and $\mathrm{O} 2$ are identified by customer disposable electro chemical sensor. The optional low range $\mathrm{CO}$ channels and $\mathrm{NO} 2$ are identified by electrochemical sensor. The resolution is (0.1\%); $1 \mathrm{PPM}$; accuracy and repeatability is $1 \%( \pm)$ of full scale for O2, CO, $\mathrm{CO}_{2}, \mathrm{SO}_{2}$ and $\mathrm{HCs} 2 \%( \pm)$ of full scale for NOx; available ranges is $(0-5.00 \% / 10.00 \% \mathrm{CO}$ (standard range), (0-2000/5000/10,000 PPM CO (low range), (0-2000/5000 PPM NOx (as NO), (0-2000/5000/10,000/20,000 PPM HC's), (0-25.0\% O2), (0-20.0\% $\left.\mathrm{CO}_{2}\right)$ and (0-800 PPM NO2) and response time is 8-10 s. 


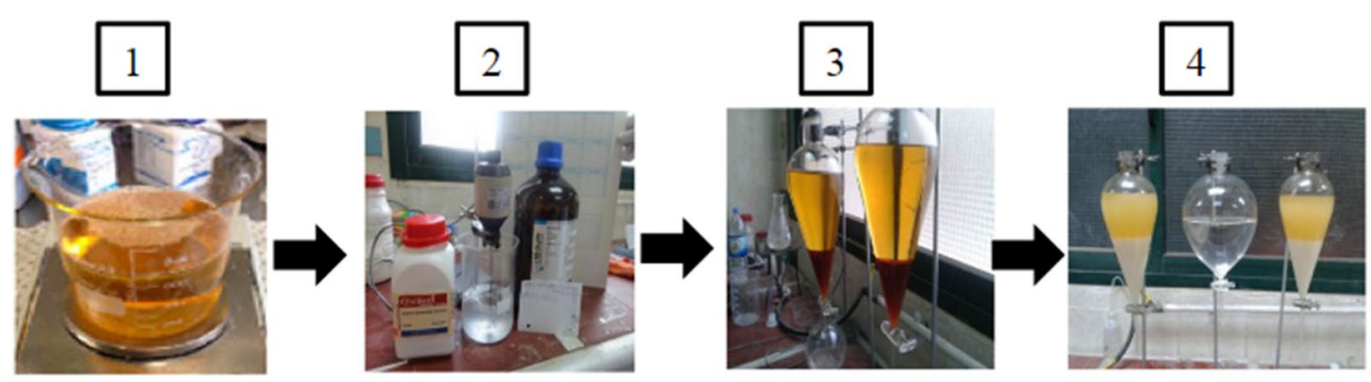

\section{Waste frving oil}

\section{Mixing of catalyst} and methanol

\section{Separation of biodiesel from glvcerol}

\section{Washing of biodiesel}

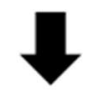

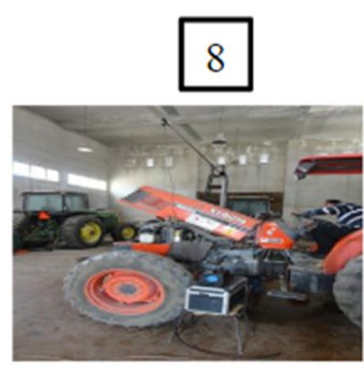

Gas emissions quality

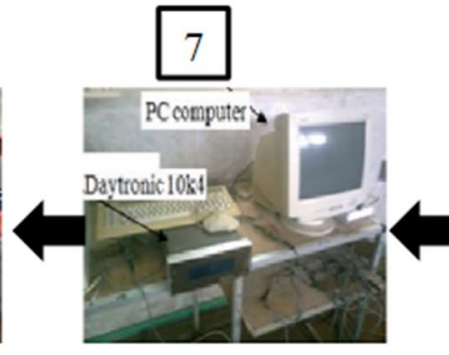

Data acquisition system

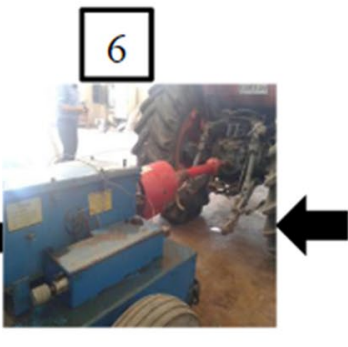

$\underline{\text { Testing tractor by }}$ dynamometer.

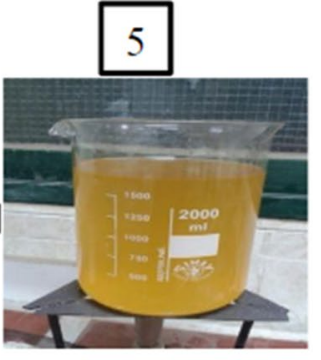

Final biodiesel sample

Scheme 1. The experimental steps.

Experimental design. The experiments were conducted as factorial experiments in two factors: the first factor was the engine load of $0,25,50,75$, and $100 \%$, and the second factor was fuel blends, percentage of $\mathrm{B}_{0}$ (100\% diesel), $\mathrm{B}_{5}$ (5\% biodiesel and $95 \%$ diesel), $\mathrm{B}_{20}\left(20 \%\right.$ biodiesel and $80 \%$ diesel), and $\mathrm{B}_{100}(100 \%$ biodiesel). Each treatment was distributed across three replications (see Scheme 1).

Performance indicators of diesel engine. PTO torque and power. The exerted power in the PTO shaft was calculated by measuring the torque and the rotational speed of the tractor PTO shaft using the following equation.

$$
P=\frac{2 \cdot \pi \cdot n \cdot \tau}{\mathrm{c}}
$$

where P: power of PTO shaft $(\mathrm{kW})$, n: rotational speed of PTO $(\mathrm{rpm}), \tau$ : torque of PTO shaft $(\mathrm{Nm})$ and c: constant equal to $60,000^{29}$.

Fuel consumption. The fuel consumption was determined by measuring the volume of consumed fuel and the time spent during each loading stage of the test, as given in the following equation:

$$
\mathrm{FC}=\frac{\mathrm{V} * 3600}{\mathrm{t}^{*} 1000},
$$

where V: volume of consumed fuel $\left(\mathrm{cm}^{3}\right)$, t: time of the test (s) and FC: fuel consumption rate $(\mathrm{L} / \mathrm{h})^{29}$.

Engine brake power. Engine brake power (BP) is the actual power of the engine, determined from the force exerted on a dynamometer connected to the PTO shaft. BP was calculated according to the technical data of the Kubota tractor as $142.5 \%$ of the power at PTO; the ratio between the engine and PTO shaft speeds (rpm) was $(2205 / 540)$, or $4.0833: 1^{29}$.

$$
\mathrm{BP}=\frac{\mathrm{PTO} \text { power }}{0.7}, \mathrm{~kW}
$$

Brake thermal efficiency. Brake thermal efficiency (BTE) is the ratio of the BP to the amount of heat energy produced from burning $1 \mathrm{~kg}$ fuel in the engine, which can be calculated using the following equation. 


\begin{tabular}{|c|c|c|c|c|c|c|c|c|c|c|c|c|c|c|}
\hline Treatments & $\begin{array}{l}\text { PTO } \\
\text { speed } \\
(\text { rpm })\end{array}$ & $\begin{array}{l}\text { PTO } \\
\text { power } \\
(\mathbf{k W})\end{array}$ & \begin{tabular}{|l} 
PTO \\
torque \\
$(\mathrm{Nm})$
\end{tabular} & $\begin{array}{l}\text { Engine } \\
\text { speed } \\
(\mathbf{r p m})\end{array}$ & $\begin{array}{l}\text { Brake } \\
\text { power } \\
(\mathbf{k W})\end{array}$ & $\begin{array}{l}\text { Brake } \\
\text { specific fuel } \\
\text { consumption } \\
\text { (BSFC) }\end{array}$ & \begin{tabular}{|l|} 
Brake \\
thermal \\
efficiency \\
(BTE)
\end{tabular} & \begin{tabular}{|l} 
Fuel cons \\
$(\mathrm{kg} / \mathrm{h})$
\end{tabular} & \begin{tabular}{|l} 
brake \\
means \\
effective \\
pressure \\
$(\mathrm{kPa})$
\end{tabular} & $\mathrm{O}_{2}(\%)$ & $\mathrm{CO}_{2}(\%)$ & $\begin{array}{l}\text { CO } \\
(\mathrm{ppm})\end{array}$ & \begin{tabular}{|l} 
NO \\
$(\mathrm{ppm})$
\end{tabular} & $\begin{array}{l}\mathrm{SO}_{2} \\
\text { (ppm) }\end{array}$ \\
\hline 0 & 679.4a & $7.0 \mathrm{~d}$ & $98.6 \mathrm{e}$ & $2774.1 \mathrm{a}$ & $10.0 \mathrm{~d}$ & $1.01 \mathrm{~b}$ & $8.5 \mathrm{~d}$ & $10.2 \mathrm{e}$ & $92.9 \mathrm{e}$ & $15.27 \mathrm{a}$ & $4.20 \mathrm{e}$ & $86.00 \mathrm{c}$ & $272.5 \mathrm{e}$ & $2.00 \mathrm{e}$ \\
\hline 25 & $628.3 \mathrm{~b}$ & $24.9 \mathrm{~b}$ & 378.6d & $2565.5 \mathrm{~b}$ & $35.6 \mathrm{~b}$ & $0.42 \mathrm{~d}$ & $20.7 \mathrm{~b}$ & $14.9 \mathrm{c}$ & $356.7 \mathrm{~d}$ & $10.99 \mathrm{~b}$ & $7.37 \mathrm{~d}$ & $62.53 \mathrm{~d}$ & $450.8 \mathrm{~d}$ & $7.31 \mathrm{~d}$ \\
\hline 50 & $509.6 \mathrm{c}$ & $29.6 \mathrm{a}$ & $555.5 \mathrm{c}$ & $2080.6 c$ & $42.4 \mathrm{a}$ & $0.40 \mathrm{e}$ & $22.0 \mathrm{a}$ & $16.7 \mathrm{a}$ & $523.1 \mathrm{c}$ & $7.95 c$ & $9.68 \mathrm{c}$ & $86.25 \mathrm{c}$ & $548.8 \mathrm{~b}$ & $11.00 \mathrm{c}$ \\
\hline 100 & $69.2 \mathrm{e}$ & $4.3 \mathrm{e}$ & $597.4 \mathrm{~b}$ & $282.6 \mathrm{e}$ & $6.2 \mathrm{e}$ & $1.88 \mathrm{a}$ & $4.6 \mathrm{e}$ & $11.6 \mathrm{~d}$ & $563.1 \mathrm{~b}$ & $5.53 \mathrm{e}$ & $11.68 \mathrm{a}$ & $275.25 \mathrm{a}$ & $504.0 \mathrm{c}$ & $13.50 \mathrm{a}$ \\
\hline $\operatorname{LSD}_{0.05}$ & 4.9 & 0.2 & 3.3 & 12.1 & 0.3 & 0.01 & 0.1 & \begin{tabular}{|l|}
0.1 \\
\end{tabular} & 4.7 & 0.03 & 0.06 & 0.83 & 2.2 & 0.06 \\
\hline \multicolumn{15}{|c|}{ (B) Blends (\%) } \\
\hline 0 & $454.3 \mathrm{a}$ & $18.9 \mathrm{a}$ & $475.6 \mathrm{a}$ & $1854.8 \mathrm{a}$ & $26.9 \mathrm{a}$ & $0.79 \mathrm{~d}$ & $16.7 \mathrm{a}$ & 13.1d & $448.2 \mathrm{a}$ & $8.75 \mathrm{~d}$ & 9.03 & $159.50 \mathrm{a}$ & $460.0 \mathrm{~d}$ & $14.75 \mathrm{a}$ \\
\hline 5 & $447.0 \mathrm{~b}$ & $18.0 \mathrm{~b}$ & $460.3 \mathrm{~b}$ & $1825.2 \mathrm{~b}$ & $25.7 \mathrm{~b}$ & $0.82 \mathrm{c}$ & $15.0 \mathrm{~b}$ & $13.7 \mathrm{c}$ & $433.6 \mathrm{~b}$ & $9.06 \mathrm{c}$ & $8.90 \mathrm{~b}$ & $152.75 \mathrm{~b}$ & $463.5 \mathrm{c}$ & $12.75 \mathrm{~b}$ \\
\hline 20 & $435.6 \mathrm{c}$ & $16.7 \mathrm{c}$ & $442.1 \mathrm{c}$ & $1778.6 \mathrm{c}$ & $23.9 \mathrm{c}$ & $0.87 \mathrm{~b}$ & $13.7 \mathrm{c}$ & $13.9 \mathrm{~b}$ & $416.4 \mathrm{c}$ & $9.22 \mathrm{~b}$ & $8.93 \mathrm{~b}$ & $138.50 \mathrm{c}$ & 466.5b & \begin{tabular}{|l|l|}
10.00 \\
\end{tabular} \\
\hline $\mathrm{A} \times \mathrm{B}$ & * & * & * & * & * & * & * & * & * & * & * & * & * & * \\
\hline
\end{tabular}

Table 1. Effects of engine load percentage and fuel blends percentage on power take-off speed, power takeoff power, power take-off torque, engine speed, brake power, brake specific fuel consumption, brake thermal efficiency, fuel consumption, brake mean effective pressure, $\mathrm{O}_{2}$ percentage, $\mathrm{CO}_{2}$ percentage, $\mathrm{CO}, \mathrm{NO}$, and $\mathrm{SO}_{2}$. Means in column (s) followed by the same letter are not significant at the 0.05 level of probability. ${ }^{*}$ Significant difference at the 0.05 level of probability.

$$
\mathrm{BTE}=\frac{B P * 3600}{F C * \rho_{f} * H V},
$$

where BP: brake power $(\mathrm{kW}), \rho_{f}$ : fuel density $(\mathrm{kg} / \mathrm{L}), \mathrm{FC}$ : fuel consumption, $(\mathrm{L} / \mathrm{h})$ and HV: fuel heat value $(\mathrm{kJ} /$ $\mathrm{kg})^{29}$.

Brake specific fuel consumption. Brake specific fuel consumption (BSFC) is the consumed fuel (FC) per kg to produce $\mathrm{BP}$ of $1 \mathrm{~kW}$ at $1 \mathrm{~h}$, which can be calculated by dividing the fuel consumption $(\mathrm{kg} / \mathrm{h})$ by the corresponding $\mathrm{BP}(\mathrm{kW})$ in the same loading conditions, represented by different levels of engine speed, assessed with the following equation (according to $^{29}$ ).

$$
\mathrm{BCFC}=\frac{\mathrm{FC}}{\mathrm{BP}} \times \frac{\mathrm{kg}}{\mathrm{kWh}},
$$

Brake mean effective pressure. Brake mean effective pressure (BMEP) is the average pressure inside a cylinder on the surface of the piston during movement from the top to the bottom of the cylinder at each power stroke, which can be calculated using the following equation.

$$
\mathrm{BMEP}=\frac{B P * 2 * 60}{L * A * n * N}
$$

where BMEP: brake mean effective pressure, $\mathrm{kPa}$, L: piston displacement, $\mathrm{m}, \mathrm{A}$ : piston cross-sectional area, $\mathrm{m}^{2}$, $\mathrm{N}$ : engine rotation speed, rpm, N: number of engine cylinders, 2: constant for four-stroke engine and 60: constant for unit conversion, $\mathrm{s},{ }^{29}$.

Statistical analysis. All collected data were subjected to analysis of variance using the technique of ${ }^{30}$. All statistical analyses were performed according to Duncan ${ }^{31}$.

Compliance with ethical requirements. This article does not contain any studies with human or animal subjects.

\section{Results and discussion}

Performance evaluation of tractor engine. The performance of the direct-injection turbocharger diesel engine for the Kubota M-90 tractor was evaluated at different engine loads with the use of different biodiesel blends with mineral diesel to maximize the engine efficiencies of PTO torque, BP, BMEP, and BTE, while also minimizing specific fuel consumption, gas emissions, and, finally, fossil fuel consumption. The results in Table 1 

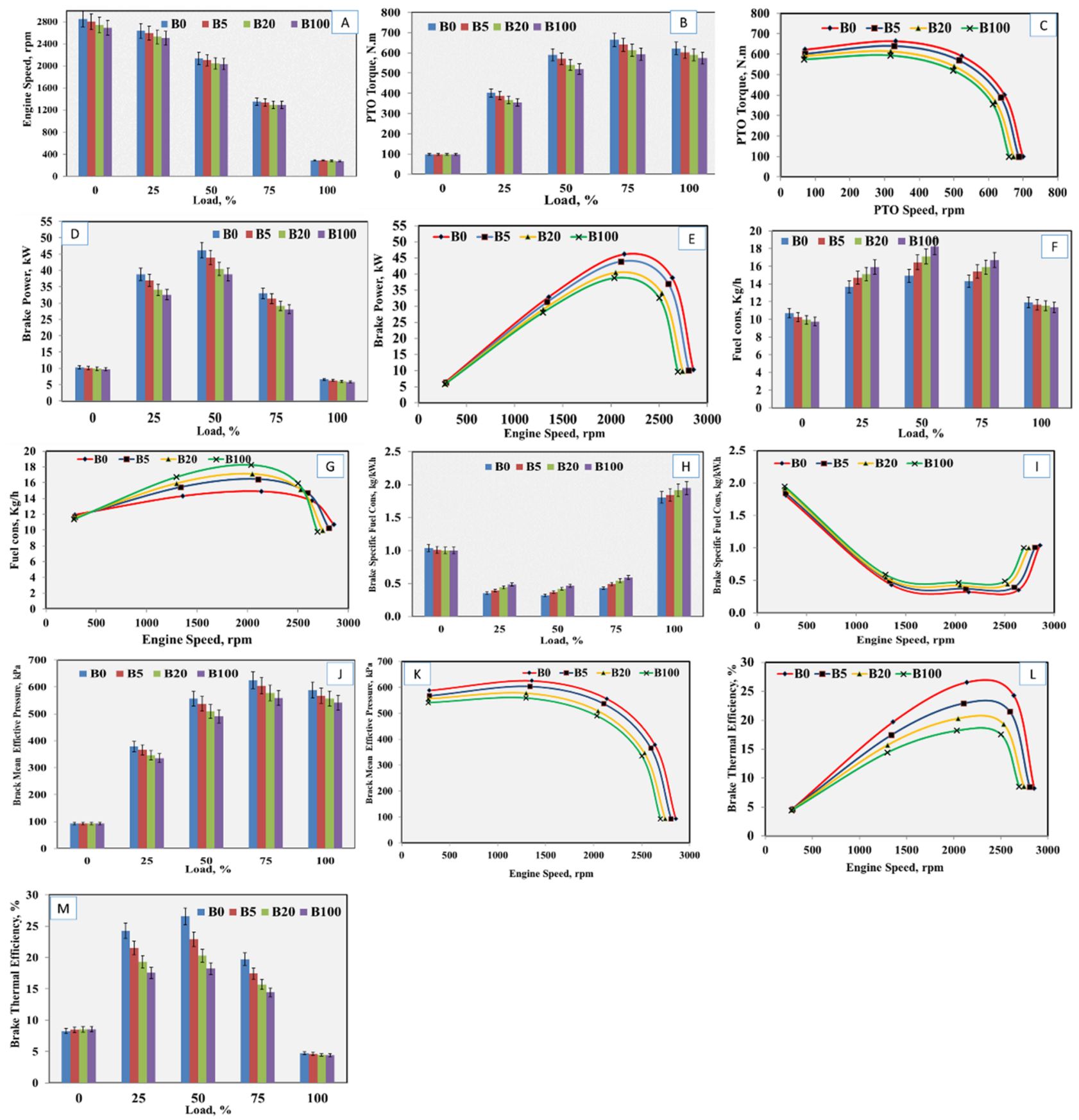

Figure 2. Effects of engine load on (a) engine speed, (b) PTO torque, (c) PTO speed on PTO torque, (d) engine load on brake power, (e) engine speed on brake power, (f) engine load on fuel consumption, (g) engine speed on fuel consumption, (h) engine load on (BSFC). (i) engine speed on (BSFC), (j) engine load on BMEP, (k) engine speed on BMEP, (l) engine speed on BTE and ( $\mathbf{m})$ engine load on BTE.

showed a significant effect of engine load percentage and fuel blend percentage and their interaction on all the studied characters.

Engine speed. For the effects of engine load percentage on engine speed, the results in Table 1 indicated the relationship between engine load percentage and engine speed in rpm was inversely proportional. The maximum engine speed was recorded at a loading of $0 \%$, and the lowest speed was at a loading of $100 \%$ (Table 1). Using $100 \%$ diesel fuel $\left(\mathrm{B}_{0}\right)$ gave the highest engine speed among all treatments, and the lowest speed was recorded with $100 \%$ biodiesel fuel $\left(\mathrm{B}_{100}\right)$. The significant interaction between engine load, percentage, and engine speed in rpm was inversely proportional, as shown in Fig. 2a. The maximum engine speed was $2854 \mathrm{rpm}$ at the loading stage of $0 \%$ using $100 \%$ diesel fuel $\left(\mathrm{B}_{0}\right)$, while the minimum speed was $276 \mathrm{rpm}$ at the loading stage of $100 \%$ 


\begin{tabular}{|c|c|c|c|c|c|c|c|c|c|c|c|c|c|c|c|}
\hline $\begin{array}{l}\text { Engine } \\
\text { load } \\
(\%)\end{array}$ & \begin{tabular}{|l} 
Biodiesel \\
blends \\
$(\%)$
\end{tabular} & \begin{tabular}{|l} 
PTO \\
speed \\
$($ rpm)
\end{tabular} & \begin{tabular}{|l|} 
PTO \\
power \\
$(\mathbf{k W})$
\end{tabular} & $\begin{array}{l}\text { PTO } \\
\text { torque } \\
(\mathrm{Nm})\end{array}$ & $\begin{array}{l}\text { Engine } \\
\text { speed } \\
(\text { rpm) }\end{array}$ & $\begin{array}{l}\text { Brake } \\
\text { power } \\
(\mathrm{kW})\end{array}$ & $\begin{array}{l}\text { Brake } \\
\text { specific fuel } \\
\text { consumption } \\
\text { (BSFC) }\end{array}$ & $\begin{array}{l}\text { Brake } \\
\text { thermal } \\
\text { efficiency } \\
\text { (BTE) }\end{array}$ & $\begin{array}{l}\text { Fuel } \\
\text { cons } \\
(\mathrm{kg} / \mathrm{h})\end{array}$ & \begin{tabular}{|l|} 
Brake \\
means \\
effective \\
pressure \\
$(\mathrm{kPa})$
\end{tabular} & $\mathrm{O}_{2}(\%)$ & $\mathrm{CO}_{2}(\%)$ & $\begin{array}{l}\text { CO } \\
(\mathrm{ppm})\end{array}$ & \begin{tabular}{|l} 
NO \\
(ppm)
\end{tabular} & $\begin{array}{l}\mathrm{SO}_{2} \\
(\mathrm{ppm})\end{array}$ \\
\hline \multicolumn{16}{|c|}{ Treatments } \\
\hline \multirow{4}{*}{0} & 0 & 699.2 & 7.2 & 98.5 & 2854.8 & 10.3 & 1.04 & 8.3 & 10.7 & 92.8 & 15.30 & 4.20 & 99.00 & 281.0 & 4.00 \\
\hline & 5 & 687.0 & 7.1 & 98.6 & 2805.0 & 10.1 & 1.01 & 8.5 & 10.3 & 92.9 & 15.20 & 4.18 & 91.00 & 274.0 & 3.00 \\
\hline & 20 & 672.0 & 6.9 & 98.7 & 2743.8 & 9.9 & 1.00 & 8.5 & 9.9 & 92.9 & 15.28 & 4.20 & 85.00 & 269.0 & 1.00 \\
\hline & 100 & 659.6 & 6.8 & 98.7 & 2692.9 & 9.7 & 1.00 & 8.5 & 9.8 & 93.0 & 15.30 & 4.20 & 69.00 & 266.0 & 0.00 \\
\hline \multirow{4}{*}{25} & 0 & 646.0 & 27.2 & 401.9 & 2637.6 & 38.8 & 0.35 & 24.3 & 13.7 & 378.6 & 10.98 & 7.39 & 54.75 & 449.5 & 11.63 \\
\hline & 5 & 635.5 & 25.9 & 389.2 & 2594.5 & 36.9 & 0.40 & 21.5 & 14.7 & 366.6 & 10.98 & 7.34 & 54.13 & 450.3 & 10.13 \\
\hline & 20 & 619.3 & 23.8 & 367.7 & 2528.7 & 34.1 & 0.44 & 19.3 & 15.1 & 346.4 & 11.03 & 7.34 & 60.25 & 452.3 & 7.50 \\
\hline & 100 & 612.5 & 22.8 & 355.7 & 2500.9 & 32.6 & 0.49 & 17.5 & 15.9 & 335.1 & 11.01 & 7.41 & 81.00 & 451.0 & 0.00 \\
\hline \multirow{4}{*}{50} & 0 & 523.4 & 32.3 & 590.7 & 2137.2 & 46.2 & 0.32 & 26.6 & 14.9 & 556.1 & 7.70 & 9.80 & 85.00 & 539.0 & 17.00 \\
\hline & 5 & 515.4 & 30.8 & 570.3 & 2104.4 & 43.9 & 0.37 & 2.9 & 16.4 & 537.3 & 7.90 & 9.70 & 85.00 & 545.0 & 15.00 \\
\hline & 20 & 501.2 & 28.3 & 540.2 & 2046.4 & 40.5 & 0.42 & 20.3 & 17.1 & 508.9 & 8.00 & 9.70 & 87.00 & 551.0 & 12.00 \\
\hline & 100 & 498.3 & 27.1 & 520.6 & 2034.4 & 38.8 & 0.47 & 18.2 & 18.2 & 490.2 & 8.20 & 9.50 & 88.00 & 560.0 & 0.00 \\
\hline \multirow{4}{*}{75} & 0 & 332.0 & 23.1 & 663.9 & 1355.7 & 32.9 & 0.43 & 19.7 & 14.3 & 625.4 & 5.48 & 11.44 & 189.75 & 549.5 & 20.13 \\
\hline & 5 & 327.2 & 21.9 & 640.9 & 1335.7 & 31.4 & 0.49 & 17.4 & 15.4 & 603.8 & 5.98 & 11.25 & 183.63 & 558.3 & 17.63 \\
\hline & 20 & 317.2 & 20.4 & 613.3 & 1295.7 & 29.1 & 0.55 & 15.7 & 15.9 & 577.7 & 6.19 & 11.29 & 165.25 & 565.3 & 14.50 \\
\hline & 100 & 316.8 & 19.7 & 593.3 & 1293.6 & 28.1 & 0.59 & 14.4 & 16.7 & 558.9 & 6.86 & 10.46 & 90.00 & 593.0 & 0.00 \\
\hline \multirow{4}{*}{100} & 0 & 70.7 & 4.6 & 622.8 & 288.7 & 6.6 & 1.81 & 4.7 & 11.9 & 588.0 & 4.30 & 12.30 & 369.00 & 481.0 & 21.00 \\
\hline & 5 & 70.1 & 4.4 & 602.3 & 286.2 & 6.3 & 1.85 & 4.6 & 11.7 & 567.4 & 5.20 & 12.00 & 350.00 & 490.0 & 18.00 \\
\hline & 20 & 68.2 & 4.2 & 590.4 & 278.5 & 6.0 & 1.92 & 4.5 & 11.5 & 556.2 & 5.60 & 12.10 & 295.00 & 495.0 & 15.00 \\
\hline & 100 & 67.8 & 4.1 & 573.9 & 276.9 & 5.8 & 1.95 & 4.4 & 11.3 & 540.9 & 7.00 & 10.30 & 87.00 & 550.0 & 0.00 \\
\hline \multicolumn{2}{|c|}{ LSD at 0.05} & 9.7 & 0.3 & 6.6 & 24.3 & 0.5 & \begin{tabular}{|l|}
0.01 \\
\end{tabular} & 0.2 & 0.1 & 9.4 & 0.07 & 0.12 & 1.66 & 4.4 & 0.13 \\
\hline
\end{tabular}

Table 2. Interaction effects between engine load percentage and fuel blends percentage on power takeoff speed, power take-off power, power take-off torque, engine speed, brake power, brake specific fuel consumption, brake thermal efficiency, fuel consumption, brake mean effective pressure, $\mathrm{O}_{2}$ percentage, $\mathrm{CO}_{2}$ percentage, $\mathrm{CO}, \mathrm{NO}$, and $\mathrm{SO}_{2}$.

using $100 \%$ biodiesel fuel $\left(\mathrm{B}_{100}\right)$, as shown in Table 2 . At all loadings, stages with increased biodiesel percentages in the blended fuel samples resulted in decreased engine speed because the heating value of biodiesel is lower than that of mineral diesel ${ }^{32-35}$.

PTO torque. The results presented in Table 1 showed the significant effect of load percentage on PTO torque, where a loading stage of $75 \%$ achieved the highest PTO torque among all loading stage percentages, and the lowest value for PTO torque was obtained with a loading stage of $0 \%$. Regarding the effects of fuel blend percentage on PTO torque, the results in Table 1 indicated that the fuel blends significantly affected PTO torque, and the highest value of this trait was achieved with $\mathrm{B}_{0}$ blend (100\% diesel fuel) in comparison to the other blend percentages, while the lowest PTO torque was given with $100 \%$ biodiesel. The relationship between the torque of PTO shaft, Nm, and PTO load in percentage, and speed in rpm are shown in Fig. 2b,c, respectively. Increased PTO load resulted in decreased PTO speed and increased PTO torque until maximum torque values were reached for all blended fuel samples at a loading stage of $75 \%$ and a speed between 316 and $332 \mathrm{rpm}$, and then the torque decreased incrementally until the maximum loading stage was reached at a minimum PTO speed. Table 2 presents the results of the interactions between engine load percentage and fuel blend percentage, indicating that the maximum PTO torque was $663 \mathrm{Nm}$ at a loading stage of 75\% and PTO speed of $332 \mathrm{rpm}$, using $100 \%$ diesel fuel $\left(\mathrm{B}_{0}\right)$, and the minimum PTO torque was $98.51 \mathrm{Nm}$ at loading stage of $0 \%$ and PTO speed of 699.19 , rpm using $100 \%$ diesel fuel $\left(\mathrm{B}_{0}\right)$. At all loading stages, increasing biodiesel percentage in the blended fuel samples resulted in decreased PTO torque, which, due to the heating value of biodiesel, was lower than that of diesel fuel ${ }^{34-36}$. The values for PTO torque were close at different biodiesel percentages at the loading stage $0 \%$, but engine performance cannot be judged at the no load stage with minimum torque, so the PTO load should be increased to see the difference between fuel types.

Engine brake power. Data in Table 1 showed that engine load percentage significantly affected BP, kW, such that engine load of 50\% achieved the highest BP, and the lowest value for BP was obtained with $100 \%$ load. The results given in Table 1 show that fuel blend percentage was significantly affected BP, whereas the highest value for this trait was achieved with the $0 \%$ blend ( $100 \%$ diesel fuel) in comparison to the other blend percentage, while the lowest BP was given with $100 \%$ biodiesel. The interactions among BP, engine load, and engine speed were significant and were as presented in Fig. 2d, e. Moreover, increased engine load resulted in decreased engine 
speed and increasing BP until the highest value was reached at the loading stage of (50\%) at engine speeds of 2034-2137 rpm for all fuel types shown in Table 2, which was due to the increased mass of burning fuel. The BP decreased until engine stop at a maximum loading stage of $100 \%$, which was due to the effects of higher frictional force at the maximum loading stage ${ }^{33-35,37}$. The maximum BP was $46.2 \mathrm{~kW}$ at a loading stage of $50 \%$ and a speed of $2137 \mathrm{rpm}$ at $100 \%$ diesel fuel $\left(\mathrm{B}_{0}\right)$, while the minimum $\mathrm{BP}$ was $5.82 \mathrm{~kW}$ at a maximum loading stage of $100 \%$ and a speed of $276 \mathrm{rpm}$ using $100 \%$ biodiesel $\left(\mathrm{B}_{100}\right)$. At all loading stages, increased biodiesel percentages resulted in decreased BP because the calorific value of biodiesel was lower than that of diesel, as noted.

Fuel consumption. Data in Table 1 showed that engine load percentage affected significantly fuel consumption; $50 \%$ load achieved the highest fuel consumption, and the lowest value for fuel consumption was obtained for $0 \%$ load. The results in Table 1 showed that fuel blends percentage significantly affected fuel consumption, and the highest value of fuel consumption was recorded with the $\mathrm{B}_{100}$ blend ( $100 \%$ biodiesel fuel), and the lowest was given with the $\mathrm{B}_{0}$ blend of $100 \%$ diesel fuel. The significant interaction between fuel consumption, $\mathrm{kg} / \mathrm{h}$ (Kilogram per hour) and each of engine load and speed are shown in Fig. 2f,g and the interaction between engine load percentage and fuel blend percentage are shown in Table 2, such that increased engine load resulted in decreased engine speed and increased fuel consumption until reaching the maximum value at a loading stage of $50 \%$ at maximum BP, which was because of the increased mass of burning fuel at this stage, and then the fuel consumption decreasing until reaching maximum loading ${ }^{33-35}$. The maximum fuel consumption was $18.24 \mathrm{~kg} / \mathrm{h}$ at an engine speed of $2034.35 \mathrm{rpm}$ using $100 \%$ biodiesel $\mathrm{B}_{100}$ at a loading stage of $50 \%$. The minimum fuel consumption was $9.76 \mathrm{~kg} / \mathrm{h}$ at an engine speed of $2692.9 \mathrm{rpm}$ using $100 \%$ biodiesel $\mathrm{B}_{100}$ at a no-load stage. At loading stages between 0 and $100 \%$, increasing biodiesel percentage resulted in increased fuel consumption, which is because the density of biodiesel was higher than that of diesel fuel.

Brake specific fuel consumption. The results in Table 1 indicated that engine load percentage significantly affected BSFC, such that the highest BSFC was achieved with an engine load of $100 \%$, while the lowest value was obtained with an engine load of 50\%. Other results shown in Table 1 indicated that increased biodiesel percentage in fuel blends produced significantly increased BSFC, and the maximum value of BSFC was given with $B_{100}$ ( $100 \%$ biodiesel fuel); the lowest was seen with $\mathrm{B}_{0}$ percentage $(100 \%$ diesel fuel). The relationship of interaction between (BSFC), (Kilogram per kilowatt hour) kg/kWh, engine load, and engine speed are shown in Fig. 2h,i, indicating that increased engine load resulted in decreased engine speed and BSFC until the minimum value was reached at a loading stage of $50 \%$ at maximum BP and fuel consumption. Then, the BSFC increased until it reached maximum value at a maximum loading stage of $100 \%$, which was due to the highest frictional force and the lowest BP occurring at this loading stage ${ }^{33-35}$. The maximum (BSFC) was $1.95 \mathrm{~kg} / \mathrm{kWh}$ at a loading stage of $100 \%$ and an engine speed of $276 \mathrm{rpm}$ using $100 \%$ biodiesel fuel $\left(\mathrm{B}_{100}\right)$; the minimum BSFC was $0.32 \mathrm{~kg} / \mathrm{kWh}$ at an engine speed of $2137 \mathrm{rpm}$ and a loading stage of $50 \%$ using $100 \%$ diesel fuel $\left(\mathrm{B}_{0}\right)$, as shown in Table 2 . At all loading stages, increased biodiesel percentages resulted in increased BSFC, except at the no loading stage. This is because the fuel consumption for biodiesel was higher than that for mineral diesel. Additionally, the calorific value of biodiesel was lower than that for diesel fuel, and the viscosity of the biodiesel was higher than that for mineral diesel, which leads to unfavorable pumping and spray characteristics ${ }^{36,38}$.

Brake mean effective pressure. The results in Table 1 indicated a significant effect of engine load percentage on $\mathrm{BMEP}$, such that the highest BMEP was given by an engine load of $75 \%$, and the other side the lowest value for BMEP was obtained for an engine load of $0 \%$. The results given in the same table indicated that increased biodiesel percentage in fuel blends significantly decreased BMEP. The maximum value of BMEP was given with the 0 blend (100\% diesel fuel), and the lowest BMEP was given with 100\% biodiesel fuel. The interaction between BMEP, $\mathrm{kPa}$, engine load, and engine speed are shown in Fig. $2 \mathrm{j}, \mathrm{k}$. The data in Table 2 show the interaction between engine load percentage and fuel blend percentage. It can be clearly seen that increased engine load resulted in decreased engine speed and increased BMEP until the maximum value was reached at a loading stage of 75\% at engine speeds between 1293 and $1355 \mathrm{rpm}$. The BMEP decreased with slight values until reaching the maximum loading stage at minimum engine speeds between 276 and $288 \mathrm{rpm}$. The maximum BMEP was $625 \mathrm{kPa}$ at an engine speed of $1355 \mathrm{rpm}$, using $100 \%$ diesel fuel $\left(\mathrm{B}_{0}\right)$ at a loading stage of $75 \%$. The minimum $\mathrm{BMEP}$ was $92 \mathrm{kPa}$ at an engine speed of $2692 \mathrm{rpm}$, using $100 \%$ biodiesel $\left(\mathrm{B}_{100}\right)$ at no loading stage. At all loading stages, increased biodiesel percentage resulted in decreased BMEP, except that there was no loading stage at which the BSFC did not change with different biodiesel percentages. This is because the effect of increased engine speed resulted in a decreased time remaining for combustion and resulted in an insufficient motion of air in the cylinder. Both effects decreased the combustion efficiency and the BMEP values, as shown in Fig. $2 \mathrm{j}$ according to s3-35,39. $^{3}$.

Brake thermal efficiency. The results shown in Table 1 cleared that engine load percentage significantly affected BTE; the highest BTE was recorded with a $50 \%$ load, and the lowest one was given with a $0 \%$ load percentage. Table 1 also indicated that fuel blend percentage significantly affected BTE, and the maximum value for BTE was given with 0 blend ( $100 \%$ diesel fuel). The lowest value was obtained with $100 \%$ biodiesel $\left(\mathrm{B}_{100}\right)$. The relationship between BTE and engine load and engine speed are shown in Figs. 2l,m. Increased engine load caused decreased engine speed and increased BTE until the maximum value was reached at a loading stage of 50\%; BTE decreased until a minimum value was reached at a maximum loading stage of $100 \%$ and minimum engine speeds between 276 and $288 \mathrm{rpm}$. The maximum BTE was $26 \%$ at a speed of $2137.17 \mathrm{rpm}$ using $100 \%$ diesel fuel $\left(\mathrm{B}_{0}\right)$ at loading stage of $50 \%$. The minimum BTE was $4.4 \%$ at speed of $276 \mathrm{rpm}$, using $100 \%$ biodiesel $\left(\mathrm{B}_{100}\right)$ at the maximum loading stage of $100 \%$, as shown in Table 2 . For all loadings stages increased biodiesel percentage resulted in 
decreased BTE, except at the no loading and maximum loading stages, where the BTE did not change with different biodiesel percentages. This is because the density of waste frying oil biodiesel was higher than that of diesel fuel, while its calorific value and volatility was lower, such that the combustion characteristics of biodiesel were lower than those of diesel fuel ${ }^{34-36,40}$.

Gas emissions quality. The results in Table 1 showed that an engine load of $0 \%$ significantly increased $\mathrm{O}_{2}$ emissions, and fuel blends of $100 \%$ biodiesel also increased $\mathrm{O}_{2}$ emissions relative to the other treatments. The relationships between $\mathrm{O}_{2}$ emissions, biodiesel percentage, engine load, and engine speed are shown in Fig. 3a,b. Increased engine load resulted in decreased $\mathrm{O}_{2}$ emissions because of the increased engine consumption of $\mathrm{O}_{2}$ to optimize fuel combustion, while increased engine speed resulted in increased $\mathrm{O}_{2}$ emissions. The maximum $\mathrm{O}_{2}$ emissions were $15.3 \%$ at the minimum loading stage for all fuel blends, while the minimum $\mathrm{O}_{2}$ emissions were $4.3 \%$ at maximum loading stage for $100 \%$ diesel fuel, as presented in Table 2 . At all loading stages, increased biodiesel percentage in the blended fuel samples resulted in increased $\mathrm{O}_{2}$ emissions, except at the no loading stage, where the oxygen content in the biodiesel was about 10 to $12 \%$ higher than that of diesel fuel ${ }^{34,35,41,42}$.

The results in Table 1 showed that engine loading of $100 \%$ significantly increased $\mathrm{CO}_{2}$ and $\mathrm{CO}$ emissions, and the fuel blend of $100 \%$ diesel fuel $\left(\mathrm{B}_{0}\right)$ increased $\mathrm{CO}_{2}$ and $\mathrm{CO}$ emissions relative to other treatments. The relationship between $\mathrm{CO}_{2}$ emissions, engine load, and engine speed are presented in Fig. $3 c$,d and Table 2. Increased engine load resulted in increased $\mathrm{CO}_{2}$ emissions until a maximum loading stage of $100 \%$ was reached, while increased engine speed resulted in decreased $\mathrm{CO}_{2}$ emissions. The maximum value for $\mathrm{CO}_{2}$ emissions was $12.3 \%$ at the maximum loading stage using $100 \%$ diesel $\left(\mathrm{B}_{0}\right)$, and the minimum $\mathrm{CO}_{2}$ emissions was $4.2 \%$ at the no loading stage for all fuel blends. At loading stages of 50,75, and 100\%, increased biodiesel percentage in the blended fuel samples resulted in decreased $\mathrm{CO}_{2}$ emissions, which due to the oxygen content in the biodiesel was about $10-12 \%$. A higher oxygen content contributes to increasing ignition quality and decrease $\mathrm{CO}_{2}$ emissions ${ }^{35,36,41}$.

The relationship between CO emissions, biodiesel percentage, engine load, and engine speed are shown in Fig. 3e,f. For all tested fuel samples, increased engine load resulted in a greater increase in CO emissions, until a maximum load was reached except at $100 \%$ biodiesel $\left(B_{100}\right)$, which increased slightly. Increased engine speed resulted in a sharp decrease in $\mathrm{CO}$ emissions until the maximum speed was reached, except at $\mathrm{B}_{100}$, which decreased slightly ${ }^{43-45}$. The maximum CO emissions value was $369 \mathrm{ppm}$ at the maximum loading stage using $100 \%$ diesel fuel $\left(\mathrm{B}_{0}\right)$, while the minimum CO emissions was $69 \mathrm{ppm}$ at the minimum loading stage using $100 \%$ biodiesel fuel $\left(\mathrm{B}_{100}\right)$. At all loading stages, increased biodiesel percentage resulted in decreased $\mathrm{CO}$ emissions except that at loading stages of $25 \%$ and $50 \%$, for which the values of $\mathrm{CO}$ emissions were close. This was because high oxygen content in biodiesel increases ignition quality and decreases $\mathrm{CO}$ emissions, so increased biodiesel percentages reduce environmental pollution ${ }^{36,43-46}$. The results in Table 2 showed that an engine load of $75 \%$ significantly increased NO emissions, and $100 \%$ biodiesel fuel $\left(\mathrm{B}_{100}\right)$ increased NO emissions relative to the other treatments.

The relationship between NO emissions, engine load, and engine speed are shown in Fig. 3g,h. Increased engine load resulted in decreased engine speed and increased $\mathrm{NO}$ emissions until the maximum value was reached at a loading stage of $75 \%$. NO emissions decreased until reach a loading stage of $100 \%$ was reached with a minimum engine speed. The maximum NO emissions were $593 \mathrm{ppm}$ at a loading stage of $75 \%$ using $100 \%$ biodiesel fuel $\left(\mathrm{B}_{100}\right)$, while the minimum $\mathrm{NO}$ emissions were $266 \mathrm{ppm}$ at the minimum loading stage using $\left(\mathrm{B}_{100}\right)$ as showed in Table 1. At all loading stages, increased biodiesel percentages in the blended fuel samples resulted in increased NO emissions, except at the no loading stage, which was due to the increased burned fuel, which resulted in increased cylinder temperature. This was responsible for thermal NOx formation. Higher flame and cylinder temperatures with high oxygen content in the biodiesel led to higher $\mathrm{NOx}^{36,43-46}$. Table 2 shows that the engine load of $100 \%$ significantly increased $\mathrm{SO}_{2}$ emissions, and $100 \%$ diesel fuel increased $\mathrm{SO}_{2}$ emissions, relative to the other treatments.

The relationship between $\mathrm{SO}_{2}$ emissions, diesel percentage, engine load, and engine speed are shown in Fig. 3I,j and Table 1. Increased engine load resulted in increased $\mathrm{SO}_{2}$ emissions, and increased engine speed resulted in decreased $\mathrm{SO}_{2}$ emissions. There were no $\mathrm{SO}_{2}$ emissions by using $100 \%$ biodiesel $\left(\mathrm{B}_{100}\right)$. The maximum $\mathrm{SO}_{2}$ emissions was $21 \mathrm{ppm}$ at maximum loading stage using $100 \%$ diesel $\left(\mathrm{B}_{0}\right)$. At all loading stages increasing biodiesel percentage in the blended fuel resulted in decreasing $\mathrm{SO}_{2}$ emissions ${ }^{43-46}$.

\section{Conclusions}

In this study, a turbocharged diesel engine for a Kubota M-90 tractor was tested using different blends of WFO biodiesel with mineral diesel. The conclusions can be summarized as (1) the best engine loading stages in terms of engine efficiencies of PTO torque, PTO power, BP, BMEP, and BTE were between 25 and $75 \%$, as well as for minimizing specific fuel consumption, gas emissions, and fuel consumption; (2) the engine loading stages of 0 and $100 \%$ did not clarify the difference between fuel blends, and the engine performance was low at these two stages, so using the tractor with a load lower than $25 \%$ or higher than $75 \%$ is inefficient; (3) using the tractor at a maximum loading stage of $100 \%$ resulted in an increase in engine vibration and noise, so it is not recommended to use this loading stage for any fuel blend. The best engine performance parameters were determined using diesel fuel, and while increasing the biodiesel percentage in the blended fuel samples resulted in worsening the performance parameters; (4) The maximum BP and BTE were $46.2 \mathrm{~kW}$ and $26 \%$, respectively, at a loading stage of $50 \%$ and speed of $2137 \mathrm{rpm}$, using $100 \%$ diesel fuel $\left(\mathrm{B}_{0}\right)$; (5) the best loading stages for the economical operation of the tractor were at the lowest BSFC at loading stages from 25 to $75 \%$ for all fuel blends and the maximum BSFC was $1.95 \mathrm{~kg} / \mathrm{kWh}$ at loading stage of $100 \%$ and engine speed of $276 \mathrm{rpm}$ using $100 \%$ biodiesel fuel $\left(\mathrm{B}_{100}\right)$. the minimum (BSFC) was $0.32 \mathrm{~kg} / \mathrm{kWh}$ at an engine speed of $2137 \mathrm{rpm}$, at a loading stage of $50 \%$ and using $100 \%$ diesel fuel $\left(\mathrm{B}_{0}\right) ;(6)$ the maximum PTO torque and BMEP were $663 \mathrm{~N} / \mathrm{m}$ at a PTO speed of 332 and $625 \mathrm{kPa}$ 

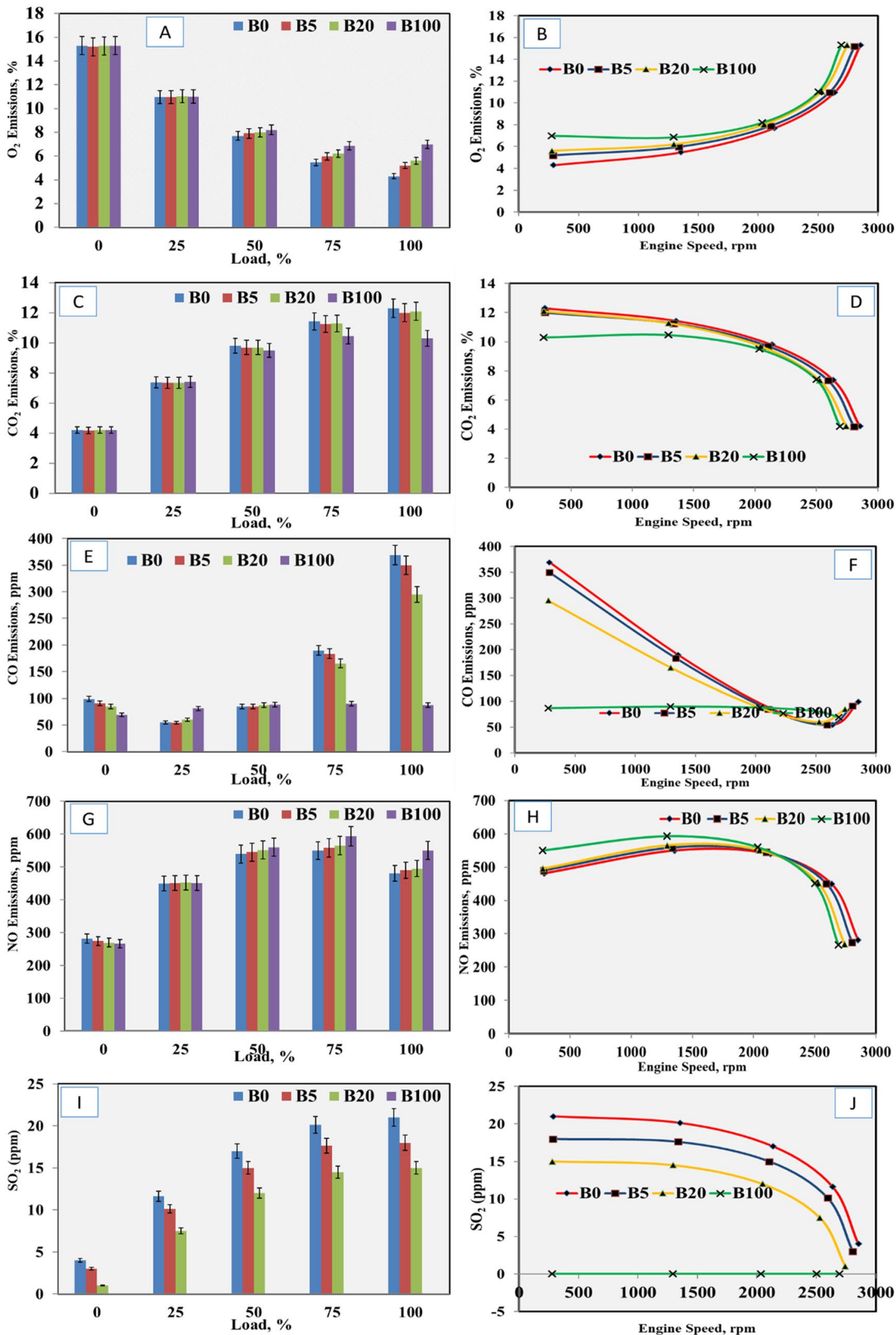

Figure 3. Effects of engine load on (a) engine load on $\mathrm{O}_{2}$ emissions, (b) engine speed on $\mathrm{O}_{2}$ emissions, (c) engine load on $\mathrm{CO}_{2}$ emissions, (d) engine speed on $\mathrm{CO}_{2}$ emissions, (e) engine load on $\mathrm{CO}$ emissions, (f) engine speed on $\mathrm{CO}$ emissions, ( $\mathbf{g}$ ) engine load on NO emissions, (h) engine speed on NO emissions, (i) engine load on $\mathrm{SO}_{2}$ emissions and (j) engine speed on $\mathrm{SO}_{2}$ emissions. 
and an engine speed of $1355 \mathrm{rpm}$ at loading stage of $75 \%$ using $100 \%$ diesel fuel $\left(\mathrm{B}_{0}\right)$, while the minimum PTO torque and BMEP were $98.51 \mathrm{~N} / \mathrm{m}$ at PTO speed of $699 \mathrm{rpm}$ and $92.78 \mathrm{kPa}$ at an engine speed of $2854.7 \mathrm{rpm}$, respectively, at no loading stage using $100 \%$ diesel fuel $\left(\mathrm{B}_{0}\right)$. At all loading stages, increased biodiesel percentage resulted in decreased PTO torque and BMEP; (7) increased engine load resulted in decreased $\mathrm{O} 2$ emissions and increased $\mathrm{CO}_{2}, \mathrm{CO}, \mathrm{NO}$, and $\mathrm{SO}_{2}$ emissions. The increased biodiesel percentage in the blended fuel samples resulted in increasing $\mathrm{O} 2$ and $\mathrm{NO}$ emissions, which resulted in decreased $\mathrm{CO}_{2}, \mathrm{CO}$, and $\mathrm{SO}_{2}$ emissions and (8) the performance of the diesel engine using diesel fuel was higher than using WFO biodiesel. The environmental impact assessment for biodiesel was better than for diesel, which was because the $\mathrm{CO}_{2}, \mathrm{CO}$, and $\mathrm{SO}_{2}$ emissions for biodiesel were lower than diesel.

Received: 15 February 2021; Accepted: 23 April 2021

Published online: 07 May 2021

\section{References}

1. Nabi, M. N. et al. Assessment of the use of a novel series of oxygenated fuels for a turbocharged diesel engine. J. Clean. Prod. 217, 549-558. https://doi.org/10.1016/j.jclepro.2019.01.249 (2019).

2. Marchetti, J., Miguel, V. \& Errazu, A. Possible methods for biodiesel production. Renew. Sustain. Energy Rev. 11, 1300-1311 (2007).

3. Choe, E. \& Min, D. B. Chemistry of deep-fat frying oils. J. Food Sci. 72, R77-R86. https://doi.org/10.1111/j.1750-3841.2007.00352.x (2007).

4. Endo, S. \& Goss, K.-U. Applications of polyparameter linear free energy relationships in environmental chemistry. Environ. Sci. Technol. 48, 12477-12491. https://doi.org/10.1021/es503369t (2014).

5. Zhang, Q., Saleh, A. S. M., Chen, J. \& Shen, Q. Chemical alterations taken place during deep-fat frying based on certain reaction products: A review. Chem. Phys. Lipid. 165, 662-681. https://doi.org/10.1016/j.chemphyslip.2012.07.002 (2012).

6. Peng, C.-Y., Lan, C.-H., Lin, P.-C. \& Kuo, Y.-C. Effects of cooking method, cooking oil, and food type on aldehyde emissions in cooking oil fumes. J. Hazard. Mater. 324, 160-167. https://doi.org/10.1016/j.jhazmat.2016.10.045 (2017).

7. Tomic, M., Micic, R., Kiss, F., Dedovic, N. \& Simikic, M. Economic and environmental performance of oil transesterification in supercritical methanol at different reaction conditions: Experimental study with a batch reactor. Energy Convers. Manage. 99, 8-19. https://doi.org/10.1016/j.enconman.2015.04.010 (2015).

8. Demirbas, A. Progress and recent trends in biodiesel fuels. Energy Convers. Manage. 50, 14-34. https://doi.org/10.1016/j.encon man.2008.09.001 (2009).

9. Lahane, S. \& Subramanian, K. A. Effect of different percentages of biodiesel-diesel blends on injection, spray, combustion, performance, and emission characteristics of a diesel engine. Fuel 139, 537-545. https://doi.org/10.1016/j.fuel.2014.09.036 (2015).

10. Ahmed, S. et al. An experimental investigation of biodiesel production, characterization, engine performance, emission and noise of Brassica juncea methyl ester and its blends. J. Clean. Prod. 79, 74-81. https://doi.org/10.1016/j.jclepro.2014.05.019 (2014).

11. Silitonga, A. S., Hassan, M. H., Ong, H. C. \& Kusumo, F. Analysis of the performance, emission and combustion characteristics of a turbocharged diesel engine fuelled with Jatropha curcas biodiesel-diesel blends using kernel-based extreme learning machine. Environ. Sci. Pollut. Res. 24, 25383-25405. https://doi.org/10.1007/s11356-017-0141-9 (2017).

12. Armas, O., Yehliu, K. \& Boehman, A. L. Effect of alternative fuels on exhaust emissions during diesel engine operation with matched combustion phasing. Fuel 89, 438-456. https://doi.org/10.1016/j.fuel.2009.09.022 (2010).

13. Lin, B.-F., Huang, J.-H. \& Huang, D.-Y. Experimental study of the effects of vegetable oil methyl ester on DI diesel engine performance characteristics and pollutant emissions. Fuel 88, 1779-1785. https://doi.org/10.1016/j.fuel.2009.04.006 (2009).

14. Shahid, E. M. \& Jamal, Y. Production of biodiesel: A technical review. Renew. Sustain. Energy Rev. 15, 4732-4745 (2011).

15. Kusumo, F. et al. Optimization of transesterification process for Ceiba pentandra oil: A comparative study between kernel-based extreme learning machine and artificial neural networks. Energy 134, 24-34. https://doi.org/10.1016/j.energy.2017.05.196 (2017).

16. Barsic, N. \& Humke, A. Performance and emissions characteristics of a naturally aspirated diesel engine with vegetable oil fuels. SAE Trans. 1173-1187 (1981).

17. Reed, T. B., Graboski, M. S. \& Gaur, S. Development and commercialization of oxygenated diesel fuels from waste vegetable oils. Biomass Bioenerg. 3, 111-115 (1992).

18. Shahid, E., Jamal, Y., Shah, A., Rumzan, N. \& Munsha, M. Effect of used cooking oil methyl ester on compression ignition engine. J. Qual. Technol. Manag. 8, 91-104 (2012).

19. Sharma, R., Pal, A. \& Sharaf, J. Production of bio-diesel from waste cooking oil. J. Eng. Res. Appl. 4, 1629-1636 (2013).

20. Valente, O. S., Pasa, V. M. D., Belchior, C. R. P. \& Sodré, J. R. Exhaust emissions from a diesel power generator fuelled by waste cooking oil biodiesel. Sci. Total Environ. 431, 57-61 (2012).

21. Simikic, M. et al. Influence of biodiesel on the performances of farm tractors: Experimental testing in stationary and non-stationary conditions. Renew. Energy 121, 677-687. https://doi.org/10.1016/j.renene.2018.01.069 (2018).

22. Prajapati, J. B., Panchal, P. R. \& Patel, T. M. Performance and emission characteristics of CI engine fuelled with diesel-biodiesel blends. IOSR J. Mech. Civ. Eng. 11, 114-121 (2014).

23. Rahman, S. A. et al. Engine performance and exhaust emission of a diesel engine using palm biodiesel blends at high idling operations. Mech. Eng. Res. J. 48-53 (2015).

24. Senthilkumar, S., Sivakumar, G. \& Manoharan, S. Investigation of palm methyl-ester bio-diesel with additive on performance and emission characteristics of a diesel engine under 8-mode testing cycle. Alex. Eng. J. 54, 423-428 (2015).

25. Canakci, M. \& Van Gerpen, J. H. Comparison of engine performance and emissions for petroleum diesel fuel, yellow grease biodiesel, and soybean oil biodiesel. Trans. ASAE 46, 937 (2003).

26. Phan, A. N. \& Phan, T. M. Biodiesel production from waste cooking oils. Fuel 87, 3490-3496 (2008).

27. Ma, F. \& Hanna, M. A. Biodiesel production: a review. Biores. Technol. 70, 1-15 (1999).

28. Hemeda, S. G., Aboukarima, A. M. \& Minyawi, M. Developing a logging unit for measuring and recording power data using Arduino board. Misr J. Agric. Eng. 34, 2053-2072 (2017).

29. Liljedahl, J. B., Turnquist, P. K., Smith, D. W. \& Hoki, M. Tractors and their power units. (Springer, 1979).

30. Gomez, K. A. \& Gomez, A. A. Statistical procedures for agricultural research. (John Wiley \& Sons, 1984).

31. Duncan, D. B. Multiple range and multiple F tests. Biometrics 11, 1-42 (1955).

32. Zhang, Y. \& Van Gerpen, J. H. Combustion analysis of esters of soybean oil in a diesel engine. Report No. 0148-7191, (SAE Technical Paper, 1996).

33. Baiju, B., Naik, M. \& Das, L. A comparative evaluation of compression ignition engine characteristics using methyl and ethyl esters of Karanja oil. Renewable Energy 34, 1616-1621 (2009).

34. Venkatesan, V., Nallusamy, N. \& Nagapandiselvi, P. Performance and emission analysis on the effect of exhaust gas recirculation in a tractor diesel engine using pine oil and soapnut oil methyl ester. Fuel 290, 120077. https://doi.org/10.1016/j.fuel.2020.120077 (2021). 
35. Karthikeyan, S., Periyasamy, M., Prathima, A. \& Yuvaraj, M. Agricultural tractor engine performance analysis using Stoechospermum marginatum microalgae biodiesel. Mater. Today Proc. 33, 3438-3442. https://doi.org/10.1016/j.matpr.2020.04.908 (2020).

36. Abed, K., El Morsi, A. K., Sayed, M. M., El Shaib, A. \& Gad, M. Effect of waste cooking-oil biodiesel on performance and exhaust emissions of a diesel engine. Egypt. J. Pet. 27, 985-989 (2018).

37. Özkan, M. Comparative study of the effect of biodiesel and diesel fuel on a compression ignition engine's performance, emissions, and its cycle by cycle variations. Energy Fuels 21, 3627-3636 (2007).

38. Fouda, M. M. G. et al. Impact of high throughput green synthesized silver nanoparticles on agronomic traits of onion. Int. J. Biol. Macromol. 149, 1304-1317. https://doi.org/10.1016/j.ijbiomac.2020.02.004 (2020).

39. Fouda, M. M. G. et al. Utilization of High throughput microcrystalline cellulose decorated silver nanoparticles as an eco-nematicide on root-knot nematodes. Colloids Surf., B 188, 110805. https://doi.org/10.1016/j.colsurfb.2020.110805 (2020).

40. Zhao, L. et al. Identification of two novel Hessian fly resistance genes H35 and H36 in a hard winter wheat line SD06165. Theor. Appl. Genet. 133, 2343-2353 (2020).

41. Baskar, P. \& Kumar, A. S. Experimental investigation on performance characteristics of a diesel engine using diesel-water emulsion with oxygen enriched air. Alex. Eng. J. 56, 137-146 (2017).

42. Ghareeb, R. Y., Alfy, H., Fahmy, A. A., Ali, H. M. \& Abdelsalam, N. R. Utilization of Cladophora glomerata extract nanoparticles as eco-nematicide and enhancing the defense responses of tomato plants infected by Meloidogyne javanica. Sci. Rep. 10, 19968. https://doi.org/10.1038/s41598-020-77005-1 (2020).

43. Ettl, J., Huber, G., Bernhardt, H. \& Thuneke, K. Real emissions of a plant oil compatible tractor measured by PEMS and on the tractor test stand. ATZoffhighway Worldwide 9, 46-52 (2016).

44. Janulevičius, A., Juostas, A. \& Čiplienè, A. Estimation of carbon-oxide emissions of tractors during operation and correlation with the not-to-exceed zone. Biosys. Eng. 147, 117-129 (2016).

45. Elkelawy, M. et al. Experimental studies on the biodiesel production parameters optimization of sunflower and soybean oil mixture and DI engine combustion, performance, and emission analysis fueled with diesel/biodiesel blends. Fuel 255, 115791 (2019).

46. Hasnain, S. M. \& Sharma, R. Evaluation of the performance and emission and spectroscopic analysis of an improved soy methyl ester. RSC Adv. 9, 26880-26893 (2019).

\section{Acknowledgements}

The authors appreciated the Taif University Researchers Supporting Project number (TURSP-2020/267), Taif University, Taif, Saudi Arabia.

\section{Author contributions}

Data curation, H.E.; formal analysis, E.E.K.; investigation, H.E.; methodology, H.E.; writing—original draft, H.E. and N.A.; writing-review and revised, N.A. and K.M.A.; funding, K.M.A.

\section{Funding}

Taif University Researchers Supporting Project number (TURSP-2020/267), Taif University, Taif, Saudi Arabia.

\section{Competing interests}

The authors declare no competing interests.

\section{Additional information}

Correspondence and requests for materials should be addressed to H.E. or N.R.A.

Reprints and permissions information is available at www.nature.com/reprints.

Publisher's note Springer Nature remains neutral with regard to jurisdictional claims in published maps and institutional affiliations.

Open Access This article is licensed under a Creative Commons Attribution 4.0 International format, as long as you give appropriate credit to the original author(s) and the source, provide a link to the Creative Commons licence, and indicate if changes were made. The images or other third party material in this article are included in the article's Creative Commons licence, unless indicated otherwise in a credit line to the material. If material is not included in the article's Creative Commons licence and your intended use is not permitted by statutory regulation or exceeds the permitted use, you will need to obtain permission directly from the copyright holder. To view a copy of this licence, visit http://creativecommons.org/licenses/by/4.0/.

(C) The Author(s) 2021 